\title{
Resiliency Scale (RS): Scale Development, Reliability and Validity Study"
}

\author{
Uğur GÜRGÂN ${ }^{* *}$
}

\begin{abstract}
The purpose of this study was to develop a new Resiliency Scale (RS) for Turkish samples. Various items from some major resiliency scales, most of them with some partial change, were collected and a pool of 228 items containing almost all possible resilience areas were obtained. This item-pool was administered to a college sample of 419. Resulting of analysis 50 item RS were obtained and administered to a new college sample of 112 participants. This second sample has also received the Rosenbaum's Learned Resourcefulness Schedule, Locus of Control Scale, Beck Hopelessness Scale and Problem Solving Inventory. Results, Pearson correlations and factor analysis, showed that the RS was a reliable and valid instrument. Reliability, validity and easy of use of the RS especially in Turkish college samples were discussed.
\end{abstract}

Key Words: Resiliency Scale, resilience, scale development, reliability, validity, factor analysis.

\footnotetext{
This study is a part of the thesis submitted to the Ankara University for the degree of Doctor of Education

Ress. Assist. Dr, Ankara University, Faculty of Educational Sciences, Educational Psychological Servicesugurgan@hotmail.com
} 


\section{SUMMARY}

The term resiliency is originally derived from Latin roots "resilience" that is used to refer to the pliant or elastic quality of a substance (Greene, 2002). Resilience is a global construct that deals with how a child copes with stress and recovery from trauma (Murphy, 1987:101). Fraser, Richman and Galinsky (1999:136) describe resilience "as the ability of individuals who adapt well to extraordinary circumstances, achieving positive and unexpected outcomes in the face of adversity."

Resilience is the process of adapting well in the face of adversity, trauma, tragedy, threats or even significant sources of stress-such as family and relationship problems, serious health problems, or workplace and financial stressors. It means "bouncing back" from difficult experiences. Research has shown that resilience is ordinary, not extraordinary. People commonly demonstrate resilience. One example is the response of many Americans to the September 11, 2001 terrorist attacks and individuals' efforts to rebuild their lives. Being resilient does not mean that a person doesn't experience difficulty or distress. Emotional pain and sadness are common in people who have suffered major adversity or trauma in their lives. In fact, the road to resilience is likely to involve considerable emotional distress. Resilience is not a trait that people either have or do not have. It involves behaviors, thoughts and actions that can be learned and developed in anyone. A combination of factors contributes to resilience. Many studies show that the primary factor in resilience is having caring and supportive relationships within and outside the family. Relationships that create love and trust provide role models and offer encouragement and reassurance help bolster a person's resilience (Comas-Diaz \& others, 2006).

Masten, Best and Garmezy (1990, as cited in Masten, 1994:7-8) concluded that resilience has been used to define three main classes of phenomena in the literature: The first type occurs in people from high-risk groups who have better than expected features. Anecdotes abound of famous or successful people from very disadvantaged backgrounds. Such studies attempt to identify the predictors of resilient high risk children. Such studies attempt to identify the predictors of good outcome in high-risk groups. The second major class of resilience phenomena refers to good adaptation despite stressful experiences. Sometimes the focus of this work is common stressor, such as divorce. Other times, it is a composite of heterogeneous stressful life events that have occurred during a recent time period. Studies examine the general effects of stressors on child behavior and the moderators that seem to enhance or reduce the effects of adversity (vulnerability and protective factors). The third class includes studies of individual differences in recovery from trauma. By definition, traumatic experiences are expected to reduce the quality of functioning. No one is invulnerable, despite the use term in the 
past. When stressors are extreme or life threatening, resilience refers to patterns of trauma.

Researchers may disagree on a single definition and also on the network of constructs surrounding resiliency, most researchers agree that resilient individuals share some outcomes. Among these are factors such as higher intelligence, lower novelty seeking, lower affiliations with delinquent peers, and an absence of externalizing behaviors, substance abuse, and juvenile delinquency (e.g., Fergusson \& Lynskey, 1996; Werner, 1989).

One of the most comprehensive studies of resiliency was conducted by Werner (1989). Initiated in 1955, this study of 698 infants on the Hawaiian island of Kauai has now continued for over 40 years. These children were considered to be at high risk for low educational achievement, future school drop-out, and alcohol abuse. The researchers noted that about one in three high-risk children grew into "competent young adults who loved well, worked well, and played well" (Werner \& Smith, 1982, p. 108). These children were called "resilient." The researchers examined individual characteristics, family structures, and the external environment to identify factors that may have helped a third of these children flourish. Results indicated that resilient children had the following characteristics: higher levels of autonomy, independence, empathy, task orientation, and curiosity than their less resilient peers. They had better problem-solving skills and better peer relationships (Werner, 1989; Werner \& Smith, 1982).

Other factors suggested to be related to resiliency are age, social support, locus of control, competence, self-esteem, temperament, social maturity, need for achievement, and past coping ability as well as family and community variables (O'Grady \& Metz, 1987; Werner \& Smith, 1982; Zimrin, 1986). In addition, family relationships and social relationships such as mentoring have been cited as related to resiliency (Werner \& Smith, 1982).

In the last 15 years, different models of resiliency have been proposed that emphasize ecological and psychological contexts. From an ecological perspective, a balance between vulnerability and protective factors is crucial in negotiating stressful life events. Resiliency is not salient in the absence of environmental stressors, nor is it assumed that individuals who seem more resilient under some environmental conditions are resilient under all conditions. As Mangham, McGrath, Reid, and Stewart (1995) said, "It may be unreasonable to hope that individuals who have faced significant adversity in their lives will emerge almost completely unscathed". Although one's resiliency may be constitutionally based, it is affected by both genetics and environmental factors. 
Purpose of this study was to develop a new Resiliency Scale (RS) for Turkish samples. Various items from some major resiliency scales, most of them with some partial change, were collected and a pool of 228 items containing almost all possible resilience areas were obtained. This item-pool was administered to a college sample of 419 (284 females $67.78 \%, 135$ males $32.22 \%$ ). Item-response format of the scale was a five point graded Likert scale ranging between "strongly description"(5) and "non description"(1). Increasing scores indicate the resiliency levels of college students. Twenty-two items were reversed.

Remaining 50 item scale had the internal consistency coefficient Cronbach's Alpha of .78 and .87. Based on the data from this 50 item RS, a factor analysis with Principal Component's technique revealed most simple factor structure following varimax rotation. RS consists of 50 items and 8 factors as whole. Total of $55.71 \%$ variance explained by these eight factors (Table 2). Factors were (1) "personal power" \%15.86, (2) "initiative" \%8.67, (3) "positive outlook" \%7.86, (4) "relationships" \%6.15, (5) "foresighted" $\% 5.53,(6)$ "purpose in life", (7) "leadership" \%4.03, and (8) "investigative" $\%$ 2.41. Test-retest reliability analysis demonstrated that there was a high correlation between the first administration of the scale and the readministration of it $(\mathrm{r}=.89, \mathrm{p}<.001, \quad \mathrm{~N}=49, \quad \mathrm{Ss}=11.57, \mathrm{t}=-2.51)$ demonstrating the similarity in measurement across times.

Resulting of analysis 50 item RS were obtained and administered to a new college sample of 112 participants. This second sample has also received the Rosenbaum's Learned Resourcefulness Schedule (RLRS), Locus of Control Scale (LCS), Beck Hopelessness Scale (BHS) and Problem Solving Inventory (PSI). Results, Pearson correlations showed that the RS total scores and RLRS scores $(.76, \mathrm{p}<.001)$, LCS total scores $(-.44, \mathrm{p}<.001)$, BHS total scores $(-.67, \mathrm{p}<.001)$, and PSI total scores $(-.79, \mathrm{p}<.001)$ were obtained as indices of the convergent validity (Table 3).

All the reliability indices obtained from the scale development study were shown that the RS was a highly reliable scale to measure resiliency in Turkish college samples. The RS revealed a conceptually meaningful factor structure and those obtained factors had high internal consistency coefficients.

Thus the general evaluation of these findings suggested that the RS has acceptable reliability and validity for Turkish college samples. Further research is needed to extend the results into new college samples.

NOTE: This is an extended summary of the following article originally written in Turkish. 


\title{
Yılmazlık Ölçeği (YÖ):Ölçek Geliştirme, Güvenirlik ve Geçerlik Çalışması*
}

\author{
Ŭgur GÜRGÂA ${ }^{* * *}$
}

ÖZ: Bu araştırmanın amacı kültürümüze uygun bir Yılmazlık Ölçeği geliştirmektir. Bu amaçla çeşitli yılmazlık ölçeklerinden aynen ya da değiştirilerek alınmış ve olası yılmazlık alanlarını büyük ölçüde kapsayan 228 maddelik bir madde havuzu oluşturulmuştur. Bu madde havuzu ilk aşamada 419 üniversite öğrencisinden oluşan bir örnekleme uygulanmıştır. Analizler sonucunda belirlenen 50 maddeden oluşan Yılmazlık Ölçeği, ikinci aşamada 112 katılımcıdan oluşan yeni bir üniversite öğrencileri örneklemine uygulanmıştır. Bu örneklem grubuna ayrıca Rosenbaum'un Öğrenilmiş Güçlülük Ölçeği, Kontrol Odağ 1 Ölçeği, Beck Umutsuzluk Ölçeği, Problem Çözme Envanteri uygulanmıştır. Madde analizi, pearson korelasyon ve faktör analizi teknikleriyle elde edilen sonuçlar, YÖ'nin tüm güvenirlik ve geçerlik göstergelerinin yüksek bir ölçek olduğunu ortaya koymuştur. Özellikle üniversite öğrencileri örnekleminde güvenli ve kolay kullanılabilecek bir araç olduğu tartışılmıştır.

Anahtar Sözcükler:Yılmazlık, yılmaz, ölçek geliştirme, güvenirlik, geçerlik, faktör analizi.

\footnotetext{
Bu çalışma Prof. Dr. Üstün Dökmen'in danışmanlığında yapılan “Grupla Psikolojik Danışmanın Üniversite Öğrencilerinin Yılmazlık Düzeylerine Etkisi” isimli doktora tezinin bir gereği olarak geliştirilen ölçek çalışmasından oluşmaktadır.

Arş. Gör. Dr., Ankara Üniversitesi, Eğitim Bilimleri Fakültesi, Eğitimde Psikolojik Hizmetlerugurgan@hotmail.com
} 


\section{GİRiș}

Y1lmazlık kavramı; Latince "resiliens" (yılmaz/ sağlam) kökünden türemiştir ve bir maddenin esnek olması ve aslına kolayca dönebilmesini ifade etmektedir (Greene, 2002). Yilmazlık kelimesinin Redhouse (2002) İngilizce sözlüğündeki karşılığı dirençlilik, çabuk iyileşme gücü, zorlukları yenme gücü, esneklik olarak verilmektedir. Amerikan Heritage Sözlüğü'nde (1982) ise yılmazlık "değişim, hastalık ve kötü kaderden hızlıca kurtulma, iyileşme" anlamını taşımaktadır. Webster Yeni Yirminci Yüzyıl İngilizce Sözlüğü'ne (1958) göre de yılmazlık "sıkıştırıldıktan sonra eski haline gelmek/ dönmek ve güç, enerji, cesaret kazanmak" anlamına gelmektedir. The Random House Sözlüğü'nde (1967) yılmazlık, "sıkıştırılıp ya da esnetildikten sonra orijinal formuna ya da pozisyonuna dönebilme becerisi" olarak tanımlanmıştır.

"Yılmazlık, bir çocuğun stresle nasıl baş ettiği ve travmadan nasıl kurtulduğu/ iyileştiği ile ilgilenen genel bir kavramdır. Yılmazlık, olumlu baş etmenin sonuçları olan, uyum ve yeterlik gibi olumlu gelişme, geleceğe yönelme ve umut ile ilgilidir" (Murphy, 1987). Masten ve diğerleri (1990) yılmazlığı daha genel bir ifadeyle "zorlayıcı ve tehdit edici koşullara rağmen başarılı bir adaptasyon yeteneğine sahip olmak, bu süreçte gayret göstermek ve sonuçta da başarılı olmaktır" diye tanımlar.

Masten ve diğerleri (1990) yılmazlığın literatürde üç temel yılmazlık olgusunu tanımlamak için kullanıldığını belirtmişlerdir:

Birinci temel yılmazlık olgusu "olumsuzluklara (yüksek risk altındaki) rağmen mevcut zorlukları aşan ve beklenenden daha iyi gelişim (başarı) gösteren bireylerin ayakta kalmalarını sağlayan özellik veya kişisel bir yeteneğe sahip oldukları inancı"nı tanımlamak için kullanılmaktadır. Olumsuz ve zorlu yaşam koşullarında yetişmiş olmasına rağmen ünlü ya da başarılı olmuş kişilerin yaşam öyküleri, yüksek risk altında yetişen çocukların ve yüksek risk altındaki grupların başarılı sonuçlar elde edebileceği değişkenleri belirlemeyi amaçlayan sistematik yılmazlık çalışmalarında da karşılaşılan sonuçlar ile paralellik ve uyum göstermektedir.

İkinci temel yılmazlık olgusu, stresli yaşam deneyimleri karşısında bireyin çabucak uyum yapabilme yeteneğine işaret etmektedir. $\mathrm{Bu}$ tür yılmazlık olgusu çalışmalarında boşanma, ailede çatışma gibi temel bir stres faktörü odak noktası olarak alınmaktadır. Bazı çalışmaların odaklandığı nokta ise, yakın zamanda meydana gelmiş birden fazla ve farklı stres faktörlerinin bir arada incelenmesi olabilmektedir. Bu türden çalışmalar farklı stres kaynaklarının çocukların davranışları üzerindeki etkileriyle 
birlikte, çocuklar üzerindeki olumsuz etkilerini azaltan koruyucu faktörleri (protective factors) ya da incinebilirliklerini (vulnerability) arttıran faktörleri incelemektedir.

Üçüncü yılmazlık olgusu ise travmayı (anne - baba ya da kardeşin ölümü gibi) atlatmaktır. Üçüncü grup ile ilgili araştırmalar, travmanın olası etkilerinden kurtulma konusunda önemli rol oynayan bireysel özellikler ve farklılıkları irdeleyen çalışmalardır. Örseleyici yaşam deneyimlerinin bireyin yaşam kalitesini azaltması beklenir. İncinmezlik (invulnerability) kavramı geçmişten günümüze değin kullanılmasına rağmen, kimse gerçekten "incinmez" değildir. Stres kaynakları aşırı ya da hayatı tehdit edici boyutlara ulaştıklarında, yılmazlık, yerini travmatik yaşantıya bırakır (Masten, 1994). Kişiler bu streslerden az ya da çok etkilenebilir, bu çok normaldir. Önemli olan bu stresten kurtulabilecek güce ve belirli yeteneklere sahip olmaktır. Stres durumları ya da travmatik durumlar gelmeden tedbirlerin alınması gerekir.

Y1lmazlık, Benard (1991) tarafından gelişim sürecinde yüksek risk faktörlerinin varlığına rağmen başarılı uyumu sağlayan koruyucu mekanizmalar veya özellikler olarak tanımlanmıştır. Linquanti (1992) benzer bir tanım kullanır. Y1lmazlık, hayatlarında büyük stres ve olumsuzluklarla karşılaşmalarına rağmen, diğerlerine göre daha büyük risk altında oldukları problemlerden uzak durabilen çocuklardaki özelliktir diye açıklamaktadır (Linquanti, 1992). Bu karşılaşılan olumsuzluklar okul başarısızlığı, madde bağımlılı̆̆ı, ruh sağlığının bozulması, kurallara, kanunlara uymama, başkalarının malına zarar verme şeklinde sıralanabilir. Rutter, yılmazlık teriminin insanların stres ve olumsuzluklara gösterdiği tepkilerde gözlenen bireysel farklılıklar olgusunun artı ucu anlamına geldiğini söylemiştir (Rutter, 1990).

Henderson ve Milstein (1996) ise yılmazlık kavramını: kişiden kişiye değişen, zaman içinde artabilen veya azalabilen bir özelliktir biçiminde tanımlamıştır. Koruyucu faktörler, bir kişide veya çevrede stres yaratan durum ve koşulların etkilerini azaltan özelliklerdir. Çevresel koruyucu faktörlerden birisi de okuldur. Bu açıdan okul, olumsuzluklara karşı yılmaz tepkiler geliştirmeyi sağlayan; çevresel koşullar ve bireysel, içsel koruyucu faktörlerin gelişmesi için eğitim yaklaşımları, koruma ve etkileşim programları ve uygun müfredatı içermelidir.

Haynes (2005), y1lmaz gençlerin travmatik olaylar içeren zor durumlarda ve mücadelede başarılı ve etkili tepkiler verebilmek için yüksek düzeyde sosyal ve duygusal zekaya-SDZ (social and emotional intelligenceSEI) ve en az ortalama bilişsel ve akademik zekaya-BAZ (cognitive and 
academic intelligence-CAI) sahip olduklarını belirtmektedir. Diğer gençlerin benzer bir durumda aynı mücadeleyi ve başarıyı gösteremediklerini de vurgulamaktadır. Haynes (2005), yılmaz gençlerin yüksek düzeyde sosyal ve duygusal zeka ile ortalama bilişsel ve akademik zeka düzeyine sahip olmalarının gerektiğini vurgulamıştır.

Yılmaz Bireylerin Özellikleri

Haynes (2005) diğer gençlerle karşılaştırıldığında, yılmaz bireylerin temel özelliklerini üç başlık altında toplayarak açıklamaktadır: a) Sosyal özellikleri, b) Duygusal özellikleri, c) Bilişsel/ akademik özellikleri.

A) Sosyal özellikleri

1) Arkadaşlıklar geliştirmede yetenekli olduğunu gösterir.

2) Başkalarıyla pozitif ilişkiler kurmakta yeteneklidir.

3) Dilin uygun kullanımını gerektiren etkili iletişim becerilerine sahip olduğu görülür.

4) Gerekli olduğunda yardım bulabilir ama yardım alma noktasında isteksizdir.

B) Duygusal Özellikler

1) Güçlü bir öz-yeterlik duygusu sergiler

2) Kendine güveninin yüksek bir düzeyde olduğu görülür.

3) Yüksek öz-saygı ve kendini kabul çok açıktır.

4) Duyguları denetleme ve farkına varma becerisi gösterir.

5) Yeni durumlara çabucak adapte olabilir.

6) Kaygı ve engellenmeye dayanabilme gücünü gösterir.

C) Bilişsel/Akademik Özellikler

1) Başarı güdüsü yüksektir.

2) Geleceği düşünme ve planlama yeteneği sergiler.

3) Stresli ve travmatik olaylarla mantıklı bir şekilde mücadele eder.

4) Dışsal yüklemelerden (şans, yetenek vb.) daha çok içsel yüklemeler (çaba vb.) yapar.

5) Çevresini yine çevresindekilerin yararı için biçimlendirir ve harekete geçirir.

Özetle yılmazlık, olumsuzluklara rağmen başarmayı sağlayan kişisel nitelikleri içermektedir. Yirmi yıldan fazla süredir devam eden çalışmalar; yılmazlığın yer, zaman, yaş, cinsiyet ve kültür kadar bireyin yaşadığı farklı koşullara bağlı olarak da değişen çok boyutlu bir özellik olduğunu 
göstermiştir (Garmezy, 1985; Garmezy ve Rutter, 1985; Rutter ve arkadaşları, 1985; Werner ve Smith, 1992; Seligman ve Chickszentmihalyi, 2000).

Y1lmaz kişileri betimlemek için İngilizee literatürde "çabuk iyileşen, kendini toparlayan, güçlükleri yenme yeteneği olan, dirençli, esnek kişi”" anlamına gelen "resilient" kavramı kullanılmaktadır (Krovetz, 1999).

$\mathrm{Bu}$ araştırma kapsamında bu kişiler için Türkçe literatüre Öğülmüş (2001) tarafindan kazandırılan "yılmaz" kavramının kullanılması uygun görülmektedir. Ayrıca bir kişilik özelliği olarak yabancı literatüründe "resilience" ve "resiliency" kavramları çabuk iyileşme gücü, zorlukları yenme gücü, dirençlilik, esneklik, sağlamlılık anlamlarında kullanılmaktadır (Greene, 2002). Bu kavramın karş1lığ olarak yine Ögülmüş (2001) tarafından literatüre kazandırılmış olan "yılmazlık" kavramının kullanılması bu çalışmada tercih edilmiştir.

Y1lmazlıkla ilgili en kapsamlı boylamsal araştırmalardan biri Werner tarafından yapılmıştır. 1955'de başlanan ve Kauai'de 698 bebeğin incelendiği bu araştırma yaklaşık 40 y1l sürmüştür (Jew, Greeen ve Kroger, 1999). Başlangıçta düşük okul başarısı, okulu bırakma ve uyuşturucu madde kullanma açısından bu çocukların yüksek risk altında oldukları düşünülmüştür. $\mathrm{Bu}$ kişiler $30^{\prime} l u$ yaşlara gelinceye kadar bu araştırma sürdürülmüsstür. $\mathrm{Bu}$ çocukların yaklaşık yarısı yoksulluk içinde büyümüş, 1/6'sına zihinsel engelli tanısı konmuş, 2/3'ünde yaşamlarının ilk on yılında ciddi biçimde öğrenme güçlüğü görülmüştür. Bununla birlikte araştırmacılar, bu çocukların yaklaşık üçte birinin oldukça normal birer genç yetişkin olduklarını saptamışlardır. Bu çocuklara "yılmaz" çocuklar denmiştir. Araştırmacılar bu çocukları diğerlerinden farklı kılan etmenleri belirlemek için bu çocukların bireysel özelliklerini, aile yapılarını ve dış çevreyi incelemişlerdir. Sonuçta bu çocukların diğer akranlarına göre daha özerk, bağımsız, empatik, görev yönelimli ve meraklı oldukları, akranlarıyla daha iyi ilişkiler kurdukları ve daha iyi sorun çözme becerilerine sahip oldukları bulunmuştur. Yaş sosyal destek, denetim odağı, yeterlilik, öz saygı, mizaç, sosyal olgunluk, başarı gereksinimi ve başa çıkma becerilerinin yanı sıra, aile ve toplumla ilişkili başka bazı değişkenlerin de yılmazlıkla ilişkili etmenler arasında yer aldığı öne sürülmüştür (Jew, Greeen ve Kroger, 1999).

Yılmaz çocukların ve yetişkinlerin ortak bazı özelliklere sahip oldukları vurgulanmıştır. Yüksek zeka düzeyi, suçlu akranlarla yakınlık kurmama, ergen suçluluğundan uzak durma gibi özellikler bunlar arasında sayılabilir. Literatürde yılmaz çocukların dört önemli özelliğine işaret edilmektedir: 
1. Sosyal yetkinlik: Başkalarında olumlu tepkiler oluşturma, böylece de hem yetişkinlerle hem de akranlarıyla olumlu ilişkiler kurma yeteneği.

2. Sorun çözme becerileri: Başkalarından yardım isteme ve olayları kendi kontrolü altında planlama becerisi.

3. Özerklik: Kişinin kendi kimliğine sahip olduğu duygusu, bağımsız davranma ve bir kişinin çevresi üzerinde kontrol kurmaya çalışma yeteneği.

4. Amaçlara sahip olma ve gelecek duygusu: Bir takım amaçlara, eğitimsel beklentilere, umuda ve parlak bir geleceğe sahip olma duygusu (Krovetz, 1999).

Y1lmaz bireylerle ilgili özellikler son y1llarda birçok araştırmacının ilgisini çekmektedir. Bu ilginin nedeni incelendiğinde birçok faktörün etkili olduğu görülmektedir. Bu faktörler yılmazlık düzeyinin ölçülmesine neden gereksinim duyulduğunu da açıklamaktadır. Şiddet, yoksulluk, boşanma, bedensel, ruhsal işkence, baskı gibi yüksek riskler, çocukları ve gençleri elverişli olmayan yaşam koşullarının nasıl üstesinden gelmeleri gerektiği konusunda bir arayışa itmektedir (Grene, 2002). Bu araştırmanın bu alanlarda yapılacak yeni çalışmalara önayak olması umulmaktadır.

Risk durumları ve örseleyici yaşam koşulları altında yetişen gençlerin, gelişimlerini tehdit eden tüm olumsuzluklara rağmen nasıl başarılı olabildiklerini ve yılmaz kalabildiklerini anlamak, benzer riskler altındaki diğer çocuk ve gençlere yönelik yapılabilecek önleyici çalışmalara 1şık tutacaktır (Lambie, Leone ve Martin, 2002; Masten ve Reed, 2002). Rehberlik ve psikolojik danışma servisleri, yılmazlığın nitelikleri hakkındaki bulguları kullanabilir ve riskli öğrencilerin ihtiyaçlarını daha etkili biçimde karşılayabilmek için önleme programlarını ayarlayabilir. Yılmazlığ 1 destekleyerek, ve üniversite ortamında, koruyucu faktörleri ilerleterek, öğretim elemanlarının ve diğer personelin risk altındaki öğrencilere daha faydalı olmasını sağlayabilir.

Yılmazlık kavramı Amerika'da geliştirilmiş olması nedeniyle, yılmazlık oluşumunu çeşitli yönlerden incelemek ve bu kavramın diğer kültürlerde de genelleştirilebilirliğine ve bu özelliklerin kazanılabileceğine dikkati çekecektir. Sonuç olarak, sınırlılıklarına rağmen, bu ön çalışmanın Türk gençlerinin arasında yılmazlığın gelişiminde önemli olabilecek içsel ve dışsal faktörlerin anlaşılmasına katkıda bulunacağı umulmaktadır.

Yapılan literatür taraması sonucunda yılmazlıkla ilgili bir çok ölçeğin yurt dişında geliştirilmiş olduğu görülmüştür. Bu araçlar şunlardır: "How Resilient Are You" (Siebert, 1999), "Resiliency Attitudes Scale (R.A.S.)"(Wolin ve Wolin, 1993), "Resilience Scale" (Wagnild ve Young, 
1993), "Ability to Adapt to Life on the Streets (A.A.L.S.) (D'Abreu, 1999), "Resiliency Scale" Benneth, E.B., Novotny, J.A., Green, K.E., Kluever, R.C.(1998). "Resilience Skills" (Werner \& Smith, 1992), "Resilience and Protective Factors" (Benard, 1991), "The Resiliency Attitudes and Skills Profile" (Hurtes, 2001), "Resilience Skills and Abilities Scale" (Jew, Green \& Kroger, 1999), "Resilient Mindset Quiz" (http://www.raisingresilientkids.com/quiz/index.html).

Yabancı ülkelerde hazırlanan yılmazlık ölçeklerinin bazıları üniversite öğrencilerine yönelik bazıları ise ilköğretim ve ortaöğretim seviyesine uygun ölçeklerdir. Üniversite seviyesindeki ölçeklerin de maddeleri İngilizce'den Türkçe' ye çevrildiğinde kültüre uygun olmayan maddelerin bulunduğu ya da yılmazlık ile ilgili alan yazında belirtilen bazı boyutları içermediği görülmüştür. Bundan dolayı bu ölçeklerin tek başına üniversite seviyesinde kullanılabilecek nitelikte olmadığg görülmüştür.

Türkiye'de yılmazlıkla ilgili çalışmaların sayısı oldukça sınırlıdır. Gizir (2004) tarafından yapılan çalışmada, yoksulluk içindeki sekizinci sınıf ilköğretim okulu öğrencilerinin akademik sağlamlıklarının (academic resilience) gelişmesine yardım eden koruyucu bireysel özellikler ile çevresel faktörlerin incelenmesi amaçlanmıştır. Araştırmanın örneklemi Ankara ilinin düşük sosyo-ekonomik düzeyde olan gecekondu bölgelerindeki 6 ilköğretim okuluna devam eden 872 (439 kız, 433 erkek) sekizinci sınıf öğrencisinden oluşmaktadır. Bu çalışmada, Demografik Bilgi Formu, "Sağlamlık ve Ergen Gelişim Ölçeğì" (Resilience and Youth Development Module), "Akademik Yeterlik Ölçeği”, "Beck Umutsuzluk Ölçeği” (Beck Hopelessness Scale) ve "Nowicki-Strickland Kontrol Odağı Ölçeği" (Nowicki-Strickland Locus of Control Scale) olmak üzere beş ölçme aracı kullanılmıştır.

Gizir'in (2004) araştırmasında evdeki yüksek beklentiler, okuldaki ilişkilerde ve arkadaş ilişkilerindeki ilgi, yoksul öğrencilerin akademik sağlamlığını yordayan en temel dışsal koruyucu faktörler olarak belirlenmiştir. $\mathrm{Bu}$ bulgular, sağlamlık (resiliency/ yılmazlık) alanında yapılan diğer araştırma bulgularıyla paralellik göstermektedir (Werner ve Smith, 1992; Chao, 2000; Borman ve Overman, 2004).

Özcan (2005) tarafindan yapılan bir araştırmada lise öğrencilerinin sahip oldukları yılmazlık özellikleri ve koruyucu faktörler, ailelerinin birliktelik-boşanmışlık durumuna ve öğrencilerin cinsiyetlerine göre karşılaştırılmıştır. Ayrıca, ailelerinin birliktelik-boşanmışlık durumu ve öğrencilerin cinsiyetinin, öğrencilerin sahip oldukları yılmazlık özelliklerini ve koruyucu faktörleri yordayıp yordamadığına bakılmıştır. Araştırmanın örneklemi 70'i anne-babası boşanmış, 82'si anne-babası birlikte yaşayan 
olmak üzere, toplam 152 öğrenciden oluşmuştur. Araştırmaya katılan öğrenciler Ankara ili Mamak ilçesindeki liselerden seçilmiştir. Lise öğrencilerinin sahip oldukları yılmazlık özellikleri ve koruyucu faktörler "California Yılmazlık Değerlendirme Ölçeği” ile saptanmıştır.

Araştırmada, anne-babası birlikte olan lise öğrencilerinin sahip olduğu yılmazlık özellikleri ve koruyucu faktörler, anne babası boşanmış olanlara göre daha yüksektir. Cinsiyete göre ise anlamlı bir farklılık yoktur. Annebabası birlikte olan lise öğrencilerinin sahip olduğu toplumdaki koruyucu ilişkiler ve yüksek beklentiler; ailedeki koruyucu ilişkiler, yüksek beklentiler ve anlamlı katılımlar için olanaklar; amaçlar ve özlemler; problem çözme düzeyleri anne-babası boşanmış olanlara göre daha yüksektir. Okuldaki koruyucu ilişkiler ve yüksek beklentiler; arkadaş grubundaki koruyucu ilişkiler; öz-yetkinlik ve öz-farkındalık; empati ise öğrencilerin ailelerinin birliktelik-boşanmışlık durumuna göre anlamlı düzeyde farklılık göstermemektedir (Özcan, 2005).

Türkiye'de yukarıdaki çalışmalarda kullanılan ölçekler, ilköğretim ve ortaöğretim seviyesine uygundur. Ancak üniversite öğrencilerine yönelik geçerlik ve güvenirlik çalışması, Türkçe'ye uyarlaması yapılmış bir ölçek literatür taraması sonucunda bulunamamıştır. Bulunan ölçeklerin aynen çevirisi yerine bu ölçeklerin bazı maddelerinden yararlanılarak ve birçok ayrıntılı bilgiyi de derleyerek kapsaml, kültürümüze uygun, kolay anlaşılabilecek, kolay uygulanabilecek bir yılmazlık ölçeği geliştirmek daha işlevsel olacaktır. Bu çerçevede, bu araştırmanın amacı üniversite öğrencileri örnekleminde kullanılmak üzere Likert formatında, yılmazlık düzeyini belirleyebilecek bir yılmazlık ölçeği geliştirmektir.

\section{YÖNTEM}

Y1lmazlık konusunda bir ölçek geliştirmek amacıyla ilgili literatür taranarak kuramsal çerçeve belirlenmiştir. Ulaşılan bilgiler 1şı̆̆ında bir madde havuzu oluşturulmuştur. Yılmaz kişilerin özellikleri yabancı dil okutmanları ile Eğitim Bilimleri Fakültesi'nde Rehberlik ve Psikolojik Danışmanlık alanındaki öğretim üyelerinin görüşüne sunularak sonuçlar değerlendirilmiştir. Ayrıca yabancı ülkelerde hazırlanan yılmazlık ölçeklerinin bazı maddelerinden yararlanılarak kapsamlı bir yılmazlık ölçeği madde havuzu oluşturulmuştur.

Deneme formu oluşturulan ölçeğin maddeleri ölçme ve değerlendirme alan uzmanlarına, yedi yüksek lisans öğrencisine, yedi doktora öğrencisine ve araştırma evreninden seçilen on, son sınıf öğrencisine verilerek ölçek maddeleri ile ilgili görüşlerine başvurulmuştur. Ayrıca bu aşamada görüşlerine başvurulan uzman ve öğrencilerin ölçek maddeleriyle ilgili 
düşüncelerini detaylı alabilmek için yüz yüze görüşme yapılarak ölçeğin sorularının anlaşılırlığı, cevaplama şekli, niteliği, yönergesi, kullanışlılığı, sorulardan ne anladıkları, amaca uygunluğu hakkındaki görüşleri ayrıntılı olarak alınmıştır. Bu görüşler 1şığında ön deneme formuna şekil verilmiştir. Madde havuzunda oluşturulan toplam 228 maddeden aynı şeyleri ifade ettiği belirlenen maddeler ile yılmazlıkla ilgili olmadığı eğitim psikolojisi ile psikolojik danışma ve rehberlik alan uzmanlarınca belirlenen maddeler ve anlaşılmayan maddeler çıkarılmıştır. Uzman görüşleri doğrultusunda yılmazlık ifadelerinden iç içe olanlar ayrı maddeler halinde tekrar düzenlenmiştir. 143 olumlu madde olarak hazırlanan ölçeğin tüm maddelerinin olumlu olması ölçek geliştirme kriterlerine uygun olmadığ 1 için 71 negatif ifade ile 72 pozitif ifade olarak maddeler değiştirilmiştir. Bu işlemin ölçeğin cevaplanmasındaki yanlılıkları aza indireceği düşünülmüştür. Düzeltilmeye ihtiyaç duyulan maddelerin Türkçe ifadeleri ise Türk Dili uzmanlarına danış1larak en uygun şekle kavuşturulmuştur. Böylece 143 maddelik bir ölçek elde edilmiştir.

Yönergenin hazırlanması aşamasında yılmazlığı ölçebilmek için, ölçme ve değerlendirme ile alan uzmanlarının görüşleri de alınarak, ölçek beşli dereceli likert formatında cevaplanacak şekilde düzenlenmiştir. Ölçeğin yönergesi ve basımı da buna uygun olarak yapılmıştır. Derecelendirme, "Hiç tanımlamıyor (1), Biraz tanımlıyor (2), Orta düzeyde tanımlıyor (3), İyi tanımlıyor (4), Çok iyi tanımlıyor (5)" şeklinde yapılmakta ve puanlanmaktadır. Olumsuz maddeler ise yukarıdaki derecelemenin tam tersi şeklinde puanlanmaktadır. Puanlardaki artış yılmazlığın yüksekliğini, azalma ise yılmazlığın düşüklüğünü göstermektedir.

Ön deneme formu 143 maddeden oluşan ölçek araştırma evreninden seçilen Ankara Üniversitesi Eğitim Bilimleri Fakültesi; Rehberlik ve Psikolojik Danışma programında öğrenim gören 10, Sınıf Öğretmenliği Bölümünden 14, Okul Öncesi Öğretmenliği Bölümünden 11 ve Hacettepe Üniversitesi; Fen Bilgisi Öğretmenliği Bölümünden 16, Sınıf Öğretmenliği Bölümünden 14 toplam 65 üniversite öğrencisine uygulanmıştır. $\mathrm{Bu}$ öğrenciler bölümlerinin 2., 3 . ve 4 . sınıfında okumakta olduklarını bildirmişlerdir. Katılımcılara, ölçek maddelerindeki anlaşılmayan noktalarla ilgili soru sorabilecekleri, öneri getirebilecekleri vurgulanmıştır. $\mathrm{Bu}$ ön deneme uygulaması araştırmacı tarafindan bizzat uygulanarak anlaşılmayan ve açıklamaya ihtayaç duyulan maddelerin olup olmadığı, yönergenin anlaşılıp anlaşılmadığı, Likert tipi derecelendirmenin maddelere uygunluğu, uygulama süresinin yeterliliği ve öğrenciler üzerindeki etkileri belirlenmiştir. Ön deneme uygulaması sonucu elde edilen veriler dikkate alınarak deneme formunda gerekli değişiklikler yapılmıştır. Deneme uygulamasından sonra 
ölçeğin 31 maddesi çıkarılmış ve kalan 112 maddeden (54 olumsuz, 58 olumlu) ölçeğinson formu elde edilmiştir.

\section{Araştırma Grubu}

Örneklem sayısının belirlenmesi konusunda, Kline'ın (2000) ve Tabachnick ve Fidell'in (2001) faktör analizi için verdiği kriterler dikkate alınmıştır. Yazarlara göre faktör analizi için 100 'ün altına inilmemesi gerekmekte ve 300 kişi “iyi”, 1000 kişi ise "mükemmel" olarak değerlendirilmektedir (Kline, 2000; Tabachnick ve Fidell, 2001). Ayrıca Balcı'nın (2005:95), Anderson (1990:202)'dan aktardı ğı, 25.000.000'luk evrende tolerans gösterilebilir $\% 5$ hata için örneklem büyüklüğü 384 kişidir. Tüm bu kaynaklar ve uzman görüşleri doğrultusunda bu araştırmanın örneklemi, Ankara'da bulunan üniversitelerin farklı alanlardaki fakültelerinde okuyan yansız atama ile seçilmiş 419 gönüllü üniversite öğrencisinden oluşmuştur. 112 maddeden oluşan ilk yılmazlık ölçeği örneklem grubundaki 419 üniversite öğrencisine bir ders saati içinde, dersin yaklaşık 40 dakikası alınarak, gruplar halinde uygulanmıştır. Öğrencilerin 284 'ü kız (\% 67.78), 135’i erkektir, (\% 32.22). Grubun yaş ortalaması 21.7'dir. Kız öğrencilerin yaş ortalaması 21.49, erkek öğrencilerin yaş ortalaması ise 22.16 'dır. Yaş gruplarına göre sıralamada en kalabalık gruptan itibaren sırasıyla 133 kişi ile 21 yaşındakiler en kalabalık yaş grubunu, 86 kişi ile 22 yaşındakiler ikinci yoğun katılımcı grubu, 81 kişi ile 20 yaşındakiler üçüncü kalabalık grubu oluşturmaktadırlar.

Tablo 1. Yılmazlık Ölçeği Çalışma Grubu Üniversite ve Bölümlere Göre Dağılımı

\begin{tabular}{|l|c|c|}
\hline \multicolumn{1}{|c|}{ Sayı ve \% } & N & \% \\
\hline Üniversite ve Bölüm & 56 & 13.4 \\
\hline Hacettepe Üniversitesi İlköğretim Fen Bilgisi Öğretmenliği & 56 & 13.4 \\
\hline Ankara Üniversitesi İlköğretim Din Kültürü ve Ahlak Bil. Öğretmenliği & 47 & 11.2 \\
\hline Hacettepe Üniversitesi İlköğretim Matematik Öğretmenliği & 41 & 9.8 \\
\hline Ankara Üniversitesi Rehberlik ve Psikolojik Danışmanlık B. & 40 & 9.5 \\
\hline Hacettepe Üniversitesi Bilgisayar Mühendisliği & 36 & 8.6 \\
\hline Ankara Üniversitesi Okul Öncesi Öğretmenliği & 28 & 6.7 \\
\hline Hacettepe Üniversitesi Alman Dili Öğretmenliği & 28 & 6.7 \\
\hline Hacettepe Üniversitesi Sınıf Öğretmenliği & 28 & 6.7 \\
\hline Ankara Üniversitesi Sosyal Bilgiler Öğretmenliği & 20 & 4.8 \\
\hline Ankara Üniversitesi Beden Eğitimi Öğretmenliği & 16 & 3.8 \\
\hline Hacettepe Üniversitesi Grafik Bölümü & 12 & 2.9. \\
\hline Hacettepe Üniversitesi Biyoloji Öğretmenliği & 11 & 2.6 \\
\hline Hacettepe Üniversitesi Fizik Öğretmenliği & $\mathbf{4 1 9}$ & $\mathbf{1 0 0}$ \\
\hline Toplam & & \\
\hline
\end{tabular}


Tablo 1'de de görüldüğü gibi; 13 farklı bölümden birinci, ikinci, üçüncü ve dördüncü sınıf öğrencileri ilk uygulama çalışmamıza katılmışlardır. $\mathrm{Bu}$ kategoride en fazla katılımın olduğu ilk üç bölüm, 56'şar kişiden oluşan Hacettepe Üniversitesi İlköğretim Fen Bilgisi Öğretmenliği ile Ankara Üniversitesi İlköğretim Din Kültürü ve Ahlâk Bilgisi Öğretmenliği birinci ve ikinci sırada yer alırken, üçüncü sırada ise 47 öğrenci ile Hacettepe Üniversitesi İlköğretim Matematik Öğretmenliği Bölümü gelmektedir. Burada özellikle farklı üniversite ve bölümlerden öğrencilere ulaşılarak ölçeğin faktör analizi için elverişli verinin oluşturulmasına çalışılmıştır.

\section{Faktör Analizi}

İlk uygulamada elde edilen veriler bilgisayar ortamına aktarılmış ve SPSS 10.0 ile analiz edilmiştir.

Faktör analizi aynı yapıyı ya da niteliği ölçen değişkenleri bir araya toplayarak ölçmeyi, az sayıda faktör ile açıklamayı amaçlayan bir istatistiksel tekniktir (Büyüköztürk, 2005). Faktör analizi, birden fazla bağımlı değişkene bağlı bir değişkeni açıklamakta katkısı olan bağımsız değişkenlerin (faktörlerin) sayısını ve bu bağımlı değişkenin koordinatlarını (faktör yüklerini) bulmada başvurulan yöntemdir (Turgut, F. ve Baykul, Y., 1992). Bu araştırmada faktör analizinde bir değişken azaltma ve anlamlı kavramsal yapılara ulaşmayı amaçlayan ve uygulamada en sik ve yaygın olarak kullanılan ve göreli olarak da yorumlanması kolay olan "Temel Bileşenler" (Principal Components) ve faktör döndürme (Rotated Component Matrix) tekniği kullanılmıştır (Büyüköztürk, 2005; Tavşancıl, 2002).

İlk analizde faktör özdeğeri 1'in üzerinde olan ve toplam varyansın \% 65.58 'ini açıklayan 28 faktör ortaya çıkmıştır. Faktör analizinde aynı yapıyı ölçmeyen maddelerin ayıklanmasında genellikle belirtilen üç ölçüt, bu araştırmada dikkate alınmıştır. Bunlardan birincisi maddelerin yer aldıkları faktördeki yük değerinin yüksek olmasıdır. Bir faktörle yüksek düzeyde ilişki veren maddelerin oluşturduğu bir küme var ise bu bulgu, o maddelerin birlikte bir kavramı-yapıyı-faktörü ölçtügü anlamına gelir (Büyüköztürk, 2002). Bu aşamada faktör yük değerinin 0.45 olarak kabul edilmesi sonucu yapılan analizde toplam varyansın \%65.82'sini açıklayan 82 maddede 22 faktör ortaya çıkmıştır. 112 maddenin hiçbir faktörde yer almayan ya da birden çok birbirinden ayırt edilemeyecek kadar yakın yükler alan 30 maddesi çıkarılarak yapılan faktör analizi sonucunda toplam varyansın \%63.22'sini açıklayan 19 faktöre ulaşılmıştır. Daha sonra yapılan faktör analizlerinde ise ilk olarak toplam varyansın \%60.81'ini açıklayan 75 madde de 11 faktör, elenen maddelerden sonra yapılan ikinci uygulamada ise toplam varyansın \%59.96'sinı 57 soruda açıklayan 9 faktör bulunmuştur. Herhangi bir faktörle ilişkilendirilemeyen 7 madde çıkarıldığında en son 
denemede toplam varyansın \%57.56'sını açıklayan 50 maddenin 8 faktörde toplandığ1 görülmüştür (EK 1).

$\mathrm{Bu}$ sekiz faktörün faktör yükleri incelendiğinde ölçeğin birinci faktörü olan "Güçlü Olma"nın toplam varyansın \%16.38'ini, ikinci faktör olan "Girişimci Olma"nın toplam varyansın \%2.91'ini, üçüncü faktör olan “İyimser Olma/ Yaşama Bağlı Olma”nın toplam varyansın \%2.03 açıkladığı bulunmuştur. $\mathrm{Bu}$ sonuçlardan hareketle ölçeğin 8 faktörlü olarak kabul edilmesinin faktörlere isim verilmesi açısından da anlamlı olacağı uzman görüşleri de alınarak kararlaştırılmıştır. Bu faktörler sırasıyla "güçlü olma", "girişimci olma", "iyimser olma/ yaşama bağl1 olma", "iletiş̧im /ilişki kurma", "öngörü", "amaca ulaşma", "lider olma", "araştırıcı olma" (Tablo 2) olarak adlandırılmıştır.

$\mathrm{Bu}$ sekiz faktörün içerdiği maddeler bakımından daha kolay tanımlanabilmesine de olanak sağlayan faktör ortogonal (dik) varimax döndürme (Rotated Component Matrix) sonucundaki faktör yükleri incelendiğinde ölçeğin birinci faktörü olan "güçlü olma"nın toplam varyansın \%15.86'sın1, ikinci faktör olan "girişimci olma"nın toplam varyansın \%8.67'sini, üçüncü faktör olan “iyimser olma/ yaşama bağlı olma"nın toplam varyansın \% 7.86'sını, dördüncü faktör olan "iletişim /ilişsi kurma"nın toplam varyansın \%6.15'ini, beşinci faktör olan “öngörü"nün toplam varyansın \%5.53'ünü, altıncı faktör olan "amaca ulaşma"nın toplam varyansın \%5.20'sini, yedinci faktör olan "lider olma"nın toplam varyansin \%4.03'ünü, sekizinci faktör olan "araştırıcı olma"nın toplam varyansın \%2.41'ini açıkladığı bulunmuştur.

\section{Yılmazlık Ölçeği (YÖ) Geçerlik ve Güvenirlik Çalışmaları Yılmazlık Ölçeği Geçerlik Çalışması}

Ölçeğin geçerlik çalışmasında ölçüt geçerliği ve yap1 geçerliğine bakılmıştır. Ölçeğin ölçüt geçerliğinin incelenmesinde yılmazlıkla kavramsal ilişkisi daha önceki araştırmalarda gösterilmiş bazı değişkenlerle korelasyonları incelenmiştir. Bu değişkenler uzman kişiler tarafindan da uygun görülen kontrol odağı, problem çözme becerisi, öğrenilmiş çaresizlik, umutsuzluktur. $\mathrm{Bu}$ değişkenlerin ölçümü ile ilgili daha önce geçerlik, güvenirlik ve uyarlama çalışması yapılmış olan Kontrol Odağı Ölçeği, Problem Çözme Envanteri, Öğrenilmiş Güçlülük Envanteri, Beck Umutsuzluk Ölçeği kullanılmıştır.

\section{a) Ölçüt Geçerliği}

Uzman görüşlerine göre yılmazlık ile olumlu ve olumsuz yönde ilişkili olan kavramsal yapılar belirlenmiş̧tir. Olumlu yönde ilişkili olduğu düşünülen kavramsal yapılar, "öğrenilmiş güçlülük”, "içten kontrol odaklılık", "umutluluk", "problem çözme becerisi"dir. Olumsuz yönde 
ilişkili olduğu düşünülen kavramsal yapılar ise "öğrenilmiş güçsüzlük", "dıştan kontrol odaklılık", "umutsuzluk, yaşama negatif bakma", "problem çözme becerilerinde yetersizlik"dir. Yılmazlık ölçeği ile, bu kavramsal yapıları ölçmek amacıyla kullanılan, geçerlik ve güvenirlik çalışmaları yapılmış olan üç ölçek ile bir envanter, uzman görüşleri doğrultusunda ölçüt geçerliği için seçilmiştir. Bunlar:

1. Rosenbaum'un Öğrenilmiş Güçlülük Ölçeği (RÖGÖ),

2. Kontrol Odağı Ölçeği (KOÖ),

3. Beck Umutsuzluk Ölçeği (BUÖ),

4. Problem Çözme Envanteri (PÇE)'dir. 


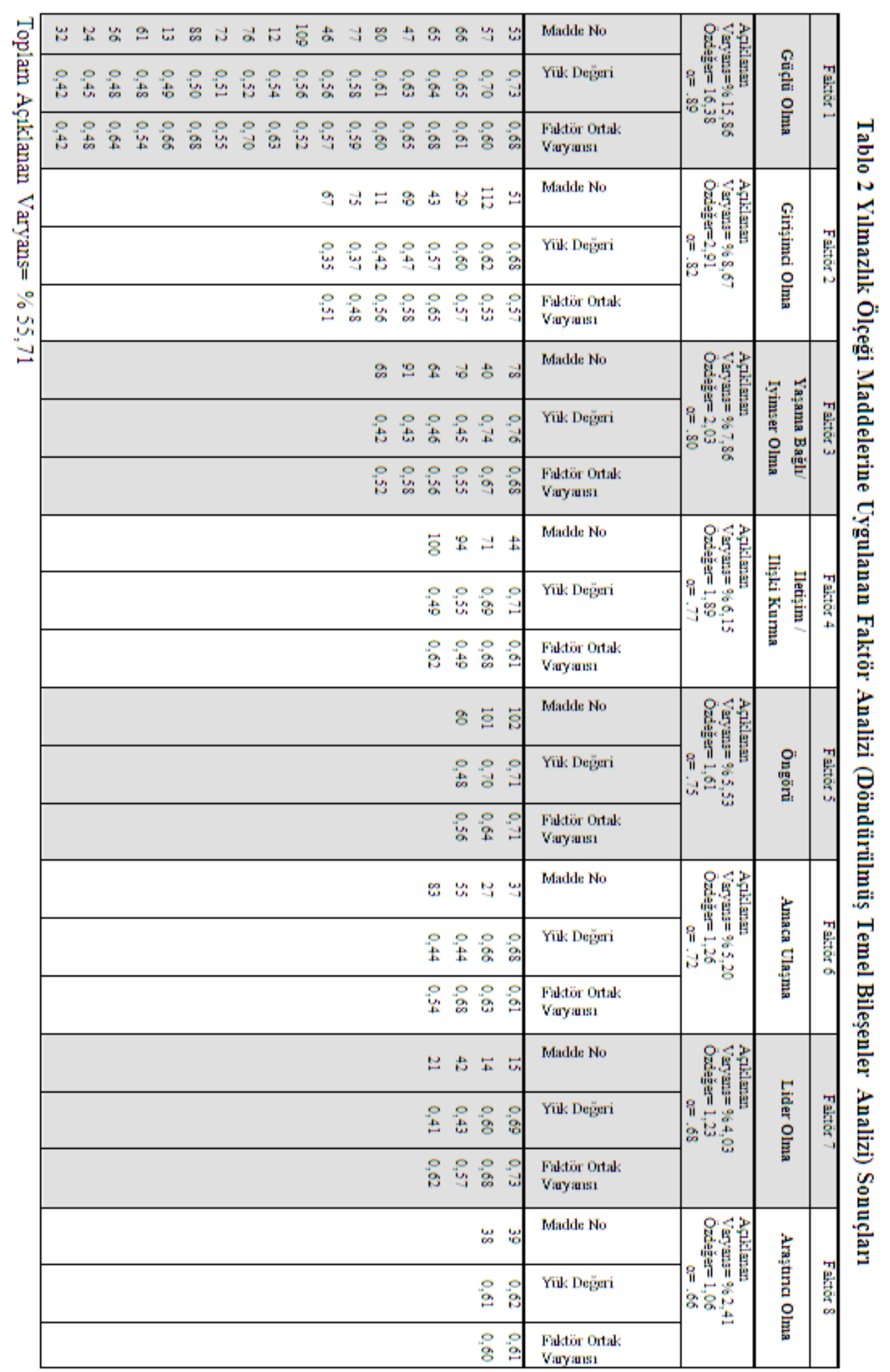


$\mathrm{Bu}$ ölçme araçlarının 112 kişilik üniversite öğrencisinden oluşan örneklem grubuna uygulanması sonucu elde edilen veriler benzer ölçekler geçerliğini sınamak amacıyla analiz edilmiştir. Bu analizin sonuçları Tablo 3 'de verilmiştir.

Tablo 3. Benzer Ölçekler Geçerliği Analiz Sonuçları ve Ölçeklerin Aritmetik Ortalama ve Standart Sapma Değerleri

\begin{tabular}{|c|c|c|c|c|c|c|c|c|}
\hline & YÖ & KOÖ & BUÖ & PÇE & RÖGÖ & & $\boldsymbol{X}$ & $\boldsymbol{S}$ \\
\hline YÖ & 1.00 & -.437 & -.670 & -.788 & .763 & YÖ & 185.54 & 31.46 \\
\hline KOÖ & -.437 & 1.00 & .457 & .526 & -.513 & KOÖ & 112.33 & 23.64 \\
\hline BUÖ & -.670 & .457 & 1.00 & .709 & -.609 & BUÖ & 4.21 & 4.63 \\
\hline PÇE & -.788 & .526 & .709 & 1.00 & -.765 & PÇE & 90.20 & 24.45 \\
\hline RÖGÖ & .763 & -.513 & -.609 & -.765 & 1.00 & RÖGÖ & 124.15 & 19.73 \\
\hline
\end{tabular}

$\mathrm{N}=112$, tüm korelasyonlar .01 düzeyinde anlamlıdır.

"Yılmazlık Ölçeği”"nden alınabilecek puan 50 ile 250 arasında değişebilmektedir. Puanın artması yılmazlık düzeyinin artışı anlamına gelmektedir. "Kontrol Odağ 1 Ölçeği”"nden alınan puan 47 ile 235 arasında değişirken, puanın artması diştan kontrol odaklılığını ifade etmektedir. "Beck Umutsuzluk Ölçeği”"nden alınabilecek puan 0 ile 20 arasında değişebilmektedir. Puanın artışı umutsuzluğun artışını ifade etmektedir. "Problem Çözme Envanteri"nden alınabilecek puan 32 ile 192 puan arasında değişebilmektedir. Puanın artması problem çözme becerilerinde düşüşe işaret etmektedir. "Rosenbaum'un Öğrenilmiş Güçlülük Ölçeği”nden alınabilecek puan ise 36 ile 180 arasında değişebilmektedir. Puanın artışı öğrenilmiş güçlülük özelliğinde artışı belirtmektedir. Tüm bu bilgiler 1şığında "Y1lmazlık Ölçeği” ile "Rosenbaum'un Öğrenilmiş Güçlülük Ölçeği”nin arasında pozitif bir korelasyonun, diğer testlerle ise negatif bir korelasyonun bulunması "Yılmazlık Ölçeğì"nin ölçmek istediği özelliği ölçmeye uygun bir araç olduğunu göstermektedir.

1) Rosenbaum'un Öğrenilmiş Güçlülük Ölçeği (Rosenbaum's Learned

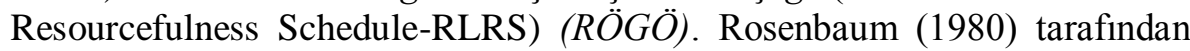
geliştirilen bu ölçek stres yaratan yaşam olayları ile ne kadar etkili biçimde baş edildiğini ve kendini denetleme becerilerini değerlendirmeyi amaçlamaktadır. Ölçeğin güvenirlik çalışmasının ilkinde iç tutarlık katsayıları çeşitli örneklemlerde .71 ile .48 arasında değişmiştir. İkinci çalışmada test-tekrar test güvenirlik katsayısının çeşitli örneklemlerde .77 ile .86 arasında değiştiği bildirilmiştir. Ölçeğin "Rotter'in İç-Dış Kontrol Odağ1 
Ölçeği” ile -.40; "Taylor Açık Kaygı Ölçeği” ile -.56 korelasyon gösterdiği çeşitli çalışmalar sonucunda bildirilmiştir (Rosenbaum, 1980). Ölçeğin uyarlanması çalışmaları Dağ (1991) ve Siva (1991) tarafindan yapılmıştır. Ölçeğin güvenirlik çalışmasında Cronbach Alfa iç tutarlık katsayısı .78 olarak bulunmuştur. Ölçeğin test tekrar test güvenirliği .80 olarak bulunmuştur. Ölçekten alınabilecek yüksek puanlar ölçekte temsil edilen stresle başa çıkma stratejilerinin sıklıkla kullanıldığına ve kendini denetleme becerilerinin yüksekliğine işaret etmektedir (Dağ, 1991).

2) Problem Çözme Envanteri-A Formu (PÇE). (Problem Solving İnventory, Form-A- PSI-A). Heppner ve Peterson (1982) tarafindan geliştirilen envanter bireyin problem çözmede kendine güvenini, bireysel kontrol duygusunu ve yaklaşım biçimini değerlendirmeyi amaçlamaktadır. Kendini problem çözmede güvenli, kontrollü hisseden ve problemden kaçma yerine yüzleşmeyi seçenlerin daha az kişisel problem bildirdikleri, kendilik algılarının daha olumlu olduğu; sosyal anksiyetelerinin daha az olduğu; kişiler arası ilişkilerde daha olumlu, daha atılgan oldukları görülmüştür. Ölçeğin güvenirlik çalışması sonucunda Cronbach Alfa iç tutarlık katsayısı .90 bulunmuştur. Ölçeğin iki defa Türkçe'ye uyarlaması yapılmıştır. İlk defa Taylan tarafindan (1990). Ölçeğin ikinci kez Türkiye uyarlaması Şahin, Şahin ve Heppner (1993) tarafından yapılmıştır. Güvenirlik çalışmasında Cronbach Alfa iç tutarlık katsayısı .88 olarak bulunmuştur. Yarıya bölme güvenirliği çalışmasında elde edilen güvenirlik katsayısı ise $r=.81$ bulunmuştur. Ölçüt bağıntılı geçerlik çalışmasında ölçeğin toplam puanı ile Beck Depresyon Envanteri arasındaki korelasyon katsayıs1 .33 ve STAI-T toplam puanı arasındaki korelasyon katsayısı ise .45 olarak bulunmuştur (Şahin, Şahin, Heppner, 1993).

3) Beck Umutsuzluk Ölçeği (BUÖ). Hopelessness Scale (HS) (Beck, Lester ve Trexler, 1974). Ölçek umutsuzluğu yansıtan psikopatolojik durumları araştırmak üzere geliştirilmiştir. Umutsuzluk, depresif bozukluğun temel özelliklerinden biri, intihar eğilimlerinin belirleyicisi, bazı fiziksel rahatsızlıklarla da yakından ilişkili olarak değerlendirilmektedir (Durak 1993; 1994; Seber, 1991). Güvenirlik çalışmasında iç tutarlık çalışmadan elde edilen Cronbach Alfa güvenirlik katsayısı .93'dür. Ölçeğin Türkiye uyarlaması Seber (1991) ve Durak (1993) tarafindan yapılmıştır. Ölçeğin farklı çalışmalarda yapılan iç tutarlık değerlendirmesinde Cronbach Alfa; 37 depresif hasta üzerinde çalış1lan araştırmada (Seber, 1991) .86 ve 373 kişilik normal ve psikiyatrik hastalar üzerinde yapılan araştırmada (Durak, 1994) ise .85 olarak bulunmuştur. Ölçeğin her bir maddesinden alınan puanlar ile tüm ölçekten alınan puanlar arasındaki madde-toplam puan korelasyonları Seber'in çalışmasında (1991) .07 ile .72 arasında, Durak'ın çalışmasında 
(1994) .31 ile .67 arasında bulunmuştur. Ölçeğin yarıya bölme güvenirliği tüm örneklem için .85'dir (Durak, 1994). Test tekrar test güvenirliği ise .74 olarak elde edilmiştir (Seber, 1991; Durak, 1994).

4) Kontrol Oda ̆̆ Ölçeği (KOÖ). (Rotter's Internal-External Locus of Control Scale). Rotter (1966) tarafindan kontrol (denetim) odağ bireylerin genellenmiş kontrol beklentilerinin içsellik- dişsallık boyutu üzerindeki konumu; pekiştiricilerin bireyin kendi içindeki ya da dışındaki güçlerin (şans veya kader) kontrolünde olduğuna dair sahip olduğu genel beklenti ya da inanç olarak tanımlanmaktadır (Rotter, 1966). Rotter tarafından geliştirilen İç-Dış Kontrol Odağı Ölçeği (RIDKOÖ) bu alandaki ihtiyacı karşılamak amacıyla farklı araştırmacılar tarafindan Türkçe'ye uyarlanmıştır (Dağ, 1990). Bu araştırmada Rotter'in Kontrol Odağ 1 Ölçeğinden daha kapsamlı ve likert formatında yeni bir kontrol odağı ölçeğine duyulan ihtiyaç üzerine bu alandaki çalışmalar göz önüne alınarak Dağ (2002) tarafindan geliştirilen Kontrol Odağ1 Ölçeği'nin kullanılması tercih edilmiştir. Bu ölçeğin iç tutarlık güvenirliği açısından yapılan analiz sonucu madde-toplam korelasyonları ortalaması .45 olmak üzere .20 ile .70 arasında değişmiştir. Ölçeğin test tekrar test pearson momentler çarpımı güvenirlik katsayısı .88'dir. Ölçüt bağıntılı geçerlik açısından KOÖ'nin diğer uygulanan diğer ölçeklerle korelasyonları, RİDKOÖ toplam ile .67, RÖGÖ toplam ile -.39, SCL-90-R GSI ile .25, NORÖTE toplam ile .46 olarak hesaplanmıştır (Dağ, 2002).

Tablo 3'de benzer testler geçerliği ile ilgili olarak yapılan analiz sonuçları verilmektedir. $\mathrm{Bu}$ analiz sonucunda Yılmazlık Ölçeği ile Rosenbaum'un Öğrenilmiş Güçlülük Ölçeği arasındaki ilişki .76 $(\mathrm{p}<.001)$ bulunmuştur. $\mathrm{Bu}$ sonuç öğrenilmiş güçlülük ile yılmazlık özellikleri arasındaki ilişkiyi beklenildiği gibi yansıtması açısından önemlidir. Daha önce belirtildiği gibi "Yılmazlık Ölçeğì" ile "Kontrol Odağı Ölçeği”, "Beck Umutsuzluk Ölçeği”, "Problem Çözme Envanteri" arasında negatif korelasyon bulunması "Y1lmazlık Ölçeği”nin geçerliliğini gösterecektir. Çizelge 7 incelendiğinde "Yılmazlık Ölçeği”"nin, "Kontrol Odağ 1 Ölçeği” ile arasındaki ilişki -.44 ( $<<.001)$, "Beck Umutsuzluk Ölçeği" ile arasındaki ilişki -.67 $(\mathrm{p}<.001)$, "Problem Çözme Envanteri” ile arasındaki ilişki -.79 $(\mathrm{p}<.001)$ 'dir. Bu sonuçlar doğrultusunda benzer testler geçerliliği açısından "Yılmazlık Ölçeği"nin ölçmek istediği amacı ölçer nitelikte olduğu söylenebilir.

\section{b) Yapı Geçerliği}

Faktör analizi bir ölçekteki maddelerin birbirini dışta tutan daha az sayıda faktöre ayrılıp ayrılmadığını ortaya çıkarmak için yapılmaktadır. Aynı 
faktör grubunda toplanan maddelere, maddelerin içeriğine göre bir isim verilmeye çalışılır. Faktör analizi ayrıca bir aracın tek boyutlu olup olmadığını test etmek amacıyla da kullanılmaktadır (Balc1, 2005). Yılmazlık Ölçeği'nin ilk aşamada tek boyutlu olup olmadığı Temel Bileşenler Analizi ile test edilmiştir. Ölçeğin birbirinden ilişkisiz ayrışması beklentisi de ortogonal (dik) varimax döndürme tekniği uygulanarak incelenmiştir.

Faktör analizi sonuçlarını değerlendirmede temel ölçüt, ölçütte yer alan değişkenlerle faktörler arasındaki korelasyonlar olarak yorumlanabilen faktör yükleridir. Faktör yüklerinin yüksek olması, değişkenin söz konusu faktör altında yer alabileceğinin bir göstergesi olarak görülür (Büyüköztürk, 2005). Faktör analizinde kullanılan "Temel Bileşenler Analizi" ve daha sonra yapılan varimax dik döndürme tekniği sonucunda toplam varyansın \%65.82'sini açıklayan 82 maddede 22 faktör ortaya çıkmıştır. Analizler tekrarlanarak hiçbir faktörde yer almayan ya da birden çok birbirinden ayırt edilemeyecek kadar yakın yükler alan ve .35 'in altında faktör yükü olan maddeler ayıklandığında, toplam varyansın \%57.56'sını açıklayan 50 maddenin 8 faktörde toplandığı görülmüştür. Yılmazlık Ölçeğinin 8 faktördeki maddelerini öz değerleri ve döndürme sonrası açılanan varyans yüzdeleri Tablo 2'de verilmiştir. Açıklanan varyans oranının \%30'un üzerinde olması davranış bilimlerinde yapılan ölçek geliştirme çalışmalarında yeterli görülmektedir (Büyüköztürk, 2005).

\section{Yılmazlık Ölçeği Güvenirlik Çalışması}

Ölçeğin güvenirliğini belirlemek için test-tekrar test güvenirliği ile ölçeğin Cronbach alfa iç tutarlık katsayısı hesaplanmıştır.

\section{a) Test Tekrar Test Tutarlılığı}

Ölçeğin güvenirliğini test etmek amacıyla çalışma evreninden seçkisiz olarak seçilen toplam 49 üniversite öğrencisine ölçek bir ay ara ile uygulanmıştır. Uygulama sonucu yapılan analiz sonucunda birinci ve ikinci uygulamada alınan puanlar arasındaki korelasyon .89 olarak bulunmuştur $(\mathrm{p}<.001, \mathrm{~N}=49, \mathrm{Ss}=11.57, \mathrm{t}=-2.51)$. Bu sonuç ölçeğin kararlı1ığı için yeterli bir kanıt olarak düşünülebilir.

\section{b) İç Tutarlıık}

İç tutarlılık için yapılan çalışmada yine aynı grupta, ilk ve ikinci uygulama toplam ölçek için ayrı ayrı hesaplanan Cronbach Alfa değeri sırasıyla .78 ve .87 olarak bulunmuştur. Geçerlik çalışmasına katılan grup için hesaplanan Cronbach Alfa değerleri de yukarıdaki değerlere oldukça yakındır (.80). 
Ölçeğin güvenirliğinin yüksekliği ve her bir maddenin temelde yılmazlık düzeyini ölçmek amacıyla geliştirilmiş olması nedeniyle, ölçekten elde edilen puanlar her bir faktör için ayrı ayrı hesaplanmayıp, ileride yapılacak analizler için ölçekten elde edilen toplam yılmazlık puanı dikkate alınacaktır. Gerektiğginde, ileride bu ölçekle yapılabilecek olası çalışmalarda, ölçek sekiz faktörlü olarak da kullanılabilir.

\section{SONUÇ VE ÖNERILER}

$\mathrm{Bu}$ çalışmada üniversite öğrencilerinin yılmazlık düzeylerini belirlemek amacıyla bir Yılmazlık Ölçeği geliştirilmiştir. Geliştirilen ölçek için gerek denek sayısı gerekse çeşitliliği bakımından istatistiksel analizlerin gerektirdiği yeterlilik sağlanmıştır. Ölçeğin son şekline ulaşabilmesi için üç farklı üniversitenin değişik bölümlerinden toplam 419 kişi çalışmaya katılmışlardır. Ölçek hem adlandırılabilir hem de toplanabilir aynı doğrultuda 8 faktörden oluşmaktadır. Toplanabilirlik ve doğrultu dikkate alındığında tek boyutlu olarak da kullanılabilecek durumdadır. Geçerlik ve güvenirlik sonuçları ölçeğin kullanıma hazır olduğunu göstermektedir.

Ölçeğin güvenirlik çalışmasında test-tekrar test güvenirliği ile ölçeğin Cronbach alfa iç tutarlık katsayısı hesaplanmıştır. Çalışma evreninden seçkisiz olarak seçilen toplam 49 üniversite öğrencisine ölçek bir ay ara ile uygulanmıştır. Uygulama sonunda yapılan analiz sonucunda birinci ve ikinci uygulamada alınan puanlar arasındaki korelasyon .89 olarak bulunmuştur $(\mathrm{p}<.001, \mathrm{~N}=49, \mathrm{Ss}=11.57, \mathrm{t}=-2.51) . \mathrm{Bu}$ sonuç ölçeğin kararlılı̆̆ 1 için oldukça iyi bir kanıt olarak düşünülebilir. Bunun yanısıra güvenirlik kanıtı olarak hesaplanan iç tutarlılık katsayıları aynı grupta farklı zamanlarda Cronbach Alfa değeri .78 ve .87 olarak bulunmuştur. Geçerlik çalışmasına katılan grup için hesaplanan Cronbach Alfa değerleri de (.80) yukarıdaki değerlere oldukça yakındır.

Yılmazlık Ölçeğinin geçerlik çalışmasında ölçüt geçerliği ve yapı geçerliğine bakılmıştır. Benzer testler geçerliği için "yılmazlık" ile, uzman görüşlerine göre pozitif ve negatif yönde ilişkili olan kavramlar belirlenmiştir. Pozitif yönde ilişkili olduğu düşünülen kavramlar: "öğrenilmiş güçlülük", “içten kontrol odaklılık", "umutluluk", "problem çözme becerisi"dir. Negatif yönde ilişkili olduğu düşünülen kavramlar ise "öğrenilmiş güçsüzlük", "dıştan kontrol odaklllık", "umutsuzluk, yaşama negatif bakabilme", "problem çözme becerilerinde yetersizlik"dir. Y1lmazlık ölçeği ile, bu özellikleri test etmek amacıyla kullanılan, geçerlik güvenirlik çalışmaları yapılmış olan üç ölçek ve bir envanter, uzman görüşleri doğrultusunda benzer testler geçerliği için seçilmiştir. Bunlar; Rosenbaum'un Öğrenilmiş Güçlülük Ölçeği (RÖGÖ), Kontrol Odağı Ölçeği 
(KOÖ), Beck Umutsuzluk Ölçeği (BUÖ), Problem Çözme Envanteri (PÇE)'dir. Yılmazlık Ölçeği ile Rosenbaum'un Öğrenilmiş Güçlülük Ölçeği arasındaki ilişki $.763(\mathrm{p}<$.001) bulunmuştur. "Y1lmazlık Ölçeği"nin, "Kontrol Odağı Ölçeği”" ile arasındaki ilişki -.437 ( $<<.001)$, "Beck Umutsuzluk Ölçeği" ile arasındaki ilişki -.670 (p<.001), "Problem Çözme Envanteri" ile arasındaki ilişki -.788 ( $\mathrm{p}<.001)$ 'dir. Daha önce belirtildiği gibi "Y1lmazlık Ölçeği” ile "Kontrol Odağı Ölçeği”, "Beck Umutsuzluk Ölçeğì", "Problem Çözme Envanteri" arasında negatif korelasyon bulunması "Yılmazlık Ölçeği”nin geçerliliğini göstermektedir. $\mathrm{Bu}$ sonuçlar doğrultusunda benzer testler geçerliliği açısından "Yılmazlık Ölçeği"nin ölçmek istediği amacı ölçer nitelikte olduğu söylenebilir.

Ölçeğin yapı geçerliğini belirlemek için faktör analizi yapılmıştır. Faktör analizi sonucunda toplam varyansın \%57.56'sını açıklayan 50 maddenin 8 faktörde toplandığ 1 görülmüştür. Yılmazlık Ölçeğindeki faktör yükleri ve açıklanan varyans yüzdesi ölçek geliştirme çalışmalarında yapı geçerliği açısından yeterli görülmektedir. Ayrıca iç tutarlılık katsayısının da $(\alpha=.78$ ve $\alpha=.87$ ) aynı zamanda bir diğer yapı geçerliği göstergesi olduğu (Anastasi ve Urbina, 1997) dikkate alındığında, Yılmazlık Ölçeğinin gerek faktör yapısıyla, gerek kavramsal olarak ilişkili olduğu daha önceden bilinen bazı değişkenlerle gösterdiği korelasyonlar esas alındığında, yılmazlığı Türkçe'de ve kültürümüzde geçerli olarak ölçen bir ölçek olduğu sonucuna varılabilir. Yüksek güvenirlik katsayısıyla birlikte düşünüldügünde de güvenle kullanılabilecek bir araç elde edildiği görülebilir. Böylece boyutları yalın olarak belirlenmiş, cevaplaması kolay, üniversite öğrencileri için uygun bir yılmazlık ölçeğinin bu araştırmayla geliştirilmesinin alana önemli bir katkı olduğu düşünülmektedir. $\mathrm{Bu}$ çerçevede, bu araştırmanın başlangıçtaki amacına ulaşıldığı söylenebilir.

Bu ölçek ile yapılacak her bir araştırma ölçeğin daha da güçlü ölçme yapabilmesi için katkı sağlayacaktır. Ayrıca ölçeğin diğer yaş gruplarında da uygulanabilir hale getirilerek geçerlik ve güvenirlik çalışmaları yapılabilir. Ölçeğin yakın ve uzak erimli yordama geçerliği araştırılmalıdır. Bununla beraber ölçeğin öğrenci örneklemi dışında da genç ve yetişkin örneklemlerinde hem sosyal beğenirlik değişkeninden bağımsız hem de geçerli ve güvenilir olarak kullanılıp kullanılmayacağının belirlenmesi gerekmektedir. 


\section{KAYNAKLAR}

American heritage dictionary, The second college edition (1982). Boston: Houghton Mifflin Co.

Anastasi, A., Urbina, S. (1997). Psychological testing (7. ed). NJ: PrenticeHall.

Balc1, A. (2005). Sosyal bilimlerde araştırma: yöntem, teknik ve ilkeler. Ankara: Pegem A Yayıncılık

Beck, A. T., Lester, D., Trexler, L. (1997). Beck Umutsuzluk Ölçeği (BUÖ). (Çev: I. Savaşır, N. H. Şahin) Ankara: Türk Psikologlar Derneği Yayınları, No:9 (Orijinal eserin yayım tarihi 1974).

Benard, B. (1991). Fostering resiliency in kids: Protective factors in the family, school and community. Portland, Oregon, Western Center for Drug-Free Schools and Communities. ED335781.

Benneth, E.B., Novotny, J.A., Green, K.E., Kluever, R.C.(1998). Confirmatory factor analysis of the Resiliency Scale. U.S. Colorado. ED422372.

Büyüköztürk, Ş. (2005). Sosyal bilimler için veri analizi elkitabı: Ístatistik, araştırma deseni, SPSS uygulamaları ve yorum. (2. baskı). Ankara: Pegem A Yayıncilik.

Comas-Diaz, L., Luthar, S. S., Maddi, S.R., (Kit) O’Neil, Ph. D., Seakvitne, K., W., Tedeschi, R. G. (2006). The road to resilience. American Psychological Association (APA) Publication. [Online]: URL: http://www.apa.org

D'abreu, R. C. (1999). The resiliency of street children in Brazil. [Online]: URL: http://www.findarticles.com/cf0/m2248/13634/59810231/print. jhtml

Dağ, İ. (1990). Kontrol odă̆ ve stresle başa çıma stratejileri ve psikolojik belirti gösterme ilişkileri. Yayımlanmamış doktora tezi, Hacettepe Üniversitesi, Sosyal Bilimler Enstitüsü, Ankara. 
Dağ, İ. (1991). Rosenbaum'un Öğrenilmiş Güçlülük Ölçeği (RÖGÖ)'nin üniversite öğrencileri için güvenirliği ve geçerliği. Türk Psikiyatri Dergisi, 2, 4, 269-274.

Dağ, İ. (2002). Kontrol odağ1 ölçeği (KOÖ): ölçek geliştirme, güvenirlik ve geçerlik çalışmas1. Türk Psikoloji Dergisi, 17 (49), 77-92.

Durak, A. (1993). Beck Umutsuzluk Ölçeği’nin geçerliği üzerine bir çalışma. Yayınlanmamış yüksek lisans tezi, Ankara Üniversitesi Sosyal Bilimler Enstitüsü, Uygulamalı Psikoloji. Ankara.

Durak, A. (1994). Beck Umutsuzluk Ölçeği’nin geçerlik ve güvenirlik çalışması. Türk Psikoloji Dergisi, 9 (31), 1-11.

Fergusson, D. M., \& Lynskey, M. T. (1996). Adolescent resiliency to family adversity. Journal of Child Psychology and Psychiatry and Allied Disciplines, 37, 281-292.

Garmezy, N. (1985). Stress resistant children: the search for protective factors, in: J. E. Stevenson (Ed.) Recent Research in Developmental Psychology, Journal of Child Psychology and Psychiatry. Book supplement No: 4.

Garmezy, N., Rutter, M. (1985). Stress, coping and development in children. New York, Mc Graw-Hill.

Greene, R. (2002). Human behavior theory: A resilience orientation. In R. Greene (Ed.), Resiliency: An integrated approach to practice, policy, and research. (pp.1-28). Washington, DC: NASW Press.

Haynes, N. M. (2005). Personalized Leadership for Effective Schooling. [Online]: URL: www.atdp.berkeley.edu/haynes_keynote_04.ppt

Henderson, N., Milstein, M. M. (1996). Resiliency in schools: Making it happen for students and educators. Thousand Oaks, California: Corwin Press.

Heppner, P. P., Peterson, C. H. (1997). Problem Çözme Envanteri-A Formu (PÇE). (Çev: Savaşır, I., Şahin, N. H.) Ankara: Türk Psikologlar Derneği Yayınları, No:9 (Orijinal eserin yayım tarihi 1982).

Hurtes, K. (2001). Measuring resiliency in youth: The resiliency attitudes and skills profile. Therapeutic Recreation Journal. 66, 89-98.

Ingilizce-Türkçe Redhouse Sözlüğü (2002). İstanbul: Sev Matbaac1lık ve Yayınc1lık A.Ş. 
Jew, C. L., Green, K. E., Kroger, J. (1999). Development and validation of a measure of resiliency. Measurement and Evaluation in Counseling and Development, 32, 75-89

Kline, P. (2000). An easy guide to factor analysis. London and New York: Routledge.

Krovetz, M. L. (1999). Fostering resiliency: Expecting all students to use their minds and hearts well. Thousand Oaks, CA: Corwin Press.

Lambie, R. A., Leone, S. D. Martin, C. K. (2002). Fostering resilience in children and youth. In J. Carlson J. Lewis, (Eds.), Counseling the adolescent: Individual, family, and school interventions (pp. 87-120). Denver: Love Publishing Company.

Linquanti, R. (1992). Using community-wide collaboration to foster resiliency in kids: a conceptual framework. San Francisco, Western Regional Center for Drug-Free Schools and Communities, Far West Laboratory for Educational Research and Development.

Mangham, C., McGrath, P., Reid, G., \& Stewart, M. (1995). Resiliency: Relevance to health promotion (detailed analysis) (Catalogue No. H39330/1-1995E). Ontario, Canada: Ministry of Supplies and Services, Office of Alcohol, Drugs and Dependence Issues.

Masten, A. (1994). Resilience in individual development: Successful adaptation despite risk and adversity. In Wang, M., Gordon, E. (Eds.) Educational resilience in inner-city America. Hillsdale, NJ: Lawrence Erlbaum.

Masten, A. S., Morison, P., Pellegrini, D. Teliegen, A. (1990). Competence under stress: risk and protective factors. In J. Rolf, A. S. Masten, D. Cicchetti, K. H. Nuechterlein S. Weintraub (Eds.), Risk and protective factors in the development of psychopathology (pp. 236-256). New York: Cambridge University Press.

Masten, A. S. Reed, M. J. (2002). Resilience in development. In C. R. Snyder S. J. Lopez (Eds.), The handbook of positive psychology (pp. 74-88). Oxford University Press.

Mrazek, P. J., \& Mrazek, D. (1987). Resilience in child maltreatment victims: A conceptual exploration. Child Abuse and Neglect, 11, 357365. 
Murphy, L. B. (1987). Further reflections on resilience. In E. J. Anthony B. J. Cohler (Eds.), The Invulnerable Child, (pp.84-105) New York: The Guilford Press.

O'Grady, D., \& Metz, R. (1987). Resilience in children at high risk for psychological disorder. Journal of Pediatric Psychology, 12, 3--23.

Öğülmüş, S. (2001). Bir kişilik özelliği olarak yılmazlık. I. Ulusal Çocuk ve Suç Sempozyumu: Nedenler ve Önleme Çalışmalarında sunuldu (29-30 Mart 2001).

Rosenbaum, M. A. (1980). Rosenbaum'un Öğrenilmiş Güçlülük Ölçĕgi (RÖGÖ) (Kendini Denetleme Ölçeği). (Çev: Savaşır, I., Şahin, N. H.) Ankara: Türk Psikologlar Derneği Yayınları, No:9 (Orijinal eserin yayım tarihi 1980).

Rotter, J. B. (1966). Generalized expectancies for internal versus external control of reinforcement. Psychological Monographs, 80, No. 609.

Rutter, M. (1990). Psychosocial resilience and protective mechanisms. In J. Rolf, A. Masten, D. Cicchetti, K. Neuchterlein, S. Weintraub (Eds.) Risk and protective factors in the development of psychopathology. New York, Cambridge University Press.

Seber, G. (1991). Beck Umutsuzluk Ölçeği'nin geçerlik ve güvenirliği üzerine bir çalışma. Yayımlanmamış doçentlik tezi, Anadolu Üniversitesi Tıp Fakültesi, Psikiyatri Bölümü. Eskişehir.

Seligman, E. P. M., Csikszentmihalyi, M.(2000). Positive psychology. American Psychologist, 55, 5-14.

Siebert, A. (1999). How Resilient Are You. New York: Guilford Press.

Siva, A. (1991). Infertile'de stresle baş etme, öğrenilmiş güçlülük ve depresyonun incelenmesi. Yayımlanmamış doktora tezi, Hacettepe Üniversitesi Nörolojik ve Psikiyatrik Bilimler Enstitüsü. Ankara.

Şahin, N., Şahin, N. H., Heppner, P. P. (1993). Psychometric properties of the Problem Solving Inventory in a group of Turkish university students. Cognitive Therapy and Research, 17, 4, 379-396.

Tavşancıl, E. (2002). Tutumların ölçülmesi ve SPSS ile veri analizi. Ankara: Nobel Yayın No: 399.

Taylan, S. (1990). Heppner'in Problem Çözme Envanterinin uyarlama, güvenirlik, ve geçerlik çalışmaları. Yayımlanmamış yüksek lisans tezi, Ankara Üniversitesi, Sosyal Bilimler Enstitüsü. Ankara. 
The Random House Dictionary of the English Language (1967). New York: Random House.

Turgut, F. ve Baykul, Y. (1992). Ölçekleme teknikleri. Ankara: ÖSYM Yayınları.

Wagnild, G. M., Young, H. M. (1993). Development and psychometric evaluation of the resilience scale. Journal of Nursing Measurement, 1, 165-178.

Webster Yeni Yirminci Yüzyıl Ingilizce Sözlüğ̈̈ (1958). New York: Webster Publishing Co.

Werner, E. E. (1989). High risk children in young adulthood: A longitudinal study from birth to 32 years. American Journal of Orthopsychiatry, 59, $72-81$.

Werner, E. E., \& Smith, R. S. (1982). Vulnerable but invincible: A longitudinal study of resilient children and youth. New York: McGraw Hill.

Werner, E. E., Smith, R. S. (1992). Overcoming the odds: High-risk children from birth to adulthood. New York: Cornell University Pres. (ED 344979)

Wolin, S., Wolin, S. (1993). The resilient self: How Survivors of troubled families rise above adversity. New York: Villard.

Yeșilyaprak, B. (1990). Gençlerde denetim odağı ve ön koșulları. V. Ulusal Psikoloji Kongresi: Psikoloji Seminer Dergisi Özel Sayısı, No: 8. İzmir: Ege Üniversitesi Basımevi.

Zimrin, H. (1986). A profile of survival. Child Abuse and Neglect, 10, 339349. 
EK: 1

YILMAZLIK ÖLÇEĞİ (YÖ)

\begin{tabular}{|l|l|}
\hline \multicolumn{2}{|c|}{ ÖLÇEKLE ILGIILİ BAZI İFADELER } \\
\hline 1 & Genel olarak olaylara kötümser bakarım \\
\hline 2 & Güçlükler karşısında yılmadan, sabırla mücadele ederim \\
\hline 3 & Kimsenin fark edemediği yaratıcı çözüm yollarını görebilirim \\
\hline 6 & $\begin{array}{l}\text { Kararlarımın sonuçlarına baktığımda genellikle isabetli kararlar } \\
\text { verdiğimi görürüm }\end{array}$ \\
\hline 7 & Çevremdeki olanak ve fırsatları kolay görüp değerlendiririm \\
\hline 8 & Başarı için olabildiğince yüksek ama ulaşılabilir hedeflerim var \\
\hline 12 & $\begin{array}{l}\text { Çevremdekiler üzerinde olumlu izlenimler bırakarak onların güvenini } \\
\text { kazanırım }\end{array}$ \\
\hline 18 & $\begin{array}{l}\text { Başkalarının üstesinden gelemeyeceği olumsuz yaşam koşulları ile } \\
\text { baş etmeyi bilirim }\end{array}$ \\
\hline 25 & Çıkabilecek problemleri önceden kestirerek önlemlerimi alırım \\
\hline 26 & Sahip olduğum özellikleri değerli bulmuyorum \\
\hline 29 & Çözüm yollarını hemen görerek uygulamaya koyarım \\
\hline 32 & Olaylar karşısında genellikle çaresiz kaldı̆̆ı̆ı hissediyorum \\
\hline 34 & $\begin{array}{l}\text { Kendi biricikliğimi içinde yaşadığım toplumla çatı̧madan ortaya } \\
\text { koyabilirim }\end{array}$ \\
\hline 37 & Genellikle bir duruma birçok yönden bakabilirim \\
\hline 43 & Yaşamımda üstlendiğim rollerimden zevk almıyorum \\
\hline 45 & Sözlü ve yazıllı olarak kendimi ifade etmeyi başarırım \\
\hline 49 & Neyin doğru neyin yanlış olduğuna karar veremem \\
\hline 50 & İnandığım şeyler için tehlikeleri göze almak zor geliyor \\
\hline
\end{tabular}

